\title{
PIEE
}

Premise : Journal of English Education and Applied Linguistics

https://fkip.ummetro.ac.id/journal/index.php/english

Umar and Suparman

\section{THE CONTRIBUTIONS OF TOURISM INDUSTRY TOWARD STUDENTS' SPEAKING MOTIVATION IN LEARNING ENGLISH}

\author{
by \\ UMAR \\ STKIP Paracendekia N W Sumbawa \\ email: umar@stkipparacendekianw.ac.id \\ SUPARMAN \\ STKIP Paracendekia N W Sumbawa \\ email: suparman@stkipparacendekianw.ac.id
}

Abstract:

This research aimed to find out The Contributions of Tourism Industry toward Students' Speaking Motivation in Learning English on Students who live around Tourism Object. The participants of this research proposal is the students who live around tourism object (case study at Kencana Beach Cottages in Labuhan Badas Sumbawa Besar). The present study used mixed method. It contain to be examined in relation to quantitative and qualitative methods of data collection and analysis. The instrument used in collecting data was questionnaire, speaking test and observation. Questionnaire and speaking test used descriptive statistics of frequencies and percentages. It was analyzed by using SPSS Program.Observation was analyzed by using qualitative method. Based on the data analysis technique above, it was found out the the contributions oftourism industry toward students' speaking motivation in learning English and to know how the contribution of tourism industry toward students' speaking motivation in English.

Keywords: Contribution, English learning, and Sstudents'” speaking mmotivation.

\section{INTRODUCTION}

Tourism Industry is the one of the largest and developing sectors of external economic activities around the world. Indeed the tourism industry does intended to change the 
growth and development rates, considerable volumes of foreign currency inflows, infrastructures development, and introduction of new management and educational experience affect in lot of sectors of economy.

By giving the positively endowment to the social life changed and economic development of the country as a whole. Futhermore, the tourism industry and the community growth are still at a very early stage of understanding, it found out from the actually work most effectively in reducing poverty through tourism development.With the reseult that giving the impact of tourism has been quatified in terms of its contribution to Gross National Product and occupation created.

The growth of tourism industry influenced of people and students who live around that place in tourism Industry. Thus, many children are involved in the majority of the activities in the tourism industry. Outward many teenagers, and even children of 3 years old were working in this area, by contributing to the growth of the sector and becoming enslaved by it. Sometime, they haveearned some money and toys from the tourists or visitors. So tha It build childrens' motivation to do it, to know and to study everything around industry area.

Certaintly, the tourism industry growth impacted to students English speaking capability, through this tourism activity influenced to their speaking improvement. This skill is very important for people interaction where people almost speak everywhere and every day through English. In this global era, many people used English as a media of communication and it makes people around the world to be easier in making communication and interaction each others. In the reality, there were many learners find it difficult to express them in spoken language in the target language. Each student has their own problems. It would be help by their own motivation.

Inndeed, this the aimed of the motivation took an important part in improving and developing learner's communicative ability. However; in Indonesia, there are many English majors who are aspiring to be part of English-speaking community. It might be true that a few of them have such desire, but the majority of English majors join the English departments because it is easier for them to get a job.

The explanation above is matching with the Juniar's argument, (2016) said that learning and motivation are equally essential for performance: Learning enables us to acquire new knowledge and skills, and motivation provides the impetus for showing what we have learned. In general, more motivated people achive at higher level to get succees in learning second or foreign language.

Speaking skill is an essential part in English for the students, which is hardly difficult to mastery by the students. According to Utamaningsih (2013) stated that speaking as one of language skill which is being taught in school, has become the main 
concern for teacher. Teacher of English should be able to find some methods to develop students' skill, especially in speaking. Teachers mostly spend much time to find an appropriate method to encourage the students so that their speaking ability.

The learners' problems in speaking English sometimes covers fluency, pronunciation and lack of vocabularies. The other side, they have abilities related to the fluency, pronunciation, vocabularies and learning motivation. But they do not have partner to practice their abilities. So, they had lost or forget about some vocabularies, fluency and pronunciation. The problems in this research are students' lack of speaking motivation in learning English. So that, they have to join in this tourism Industry, but it never evaluate of their motivation. Moreover, they just come to interacted with guests or did sell-buy interaction. But in deeply, it is really interesting thing to correlated to their English learning motivation, in order it will be able to find out their speaking motivation degrees percentage in joining tourism Industry.

Speaking is classified into the productive skill which takes an important part in mastering English. As productive skill, speaking becomes a measurement whether learners have mastered English or not. As stated by Fauzan (2014) in Fauzan (2016) argues that Speaking skill is very important in the context of English learning. It is because through verbal language, speaking, one enables to express his/her ideas, and thoughts and being able to speak is one of the indicators of mastering the language.

In this case, learners will think whether they have mastered the language or not by measuring their spoken ability in using the language itself. In addition, speaking naturally, as a common problem was occured in a speaking class is that teachers frequently feel difficult to involve students in the speaking activities, (Irawati, 2016). Moreover, still arguing by Irawati (2016), say that English teachers should work hard to attract the students to speak a lot in the class.

To overcome the students' speaking problem in the classroom, it needed the simple teaching process through learning speaking on repitition drills or memorization of the dialogue, trying to invite them to demonstrate what they were being memorized. This strategy is going to encourage the students be communicatively, teachers and students will occur communicative interaction. Basically, langauge is a taught process through communicaticative interaction between teachers and students. 
To attract the students' interest in speaking activity, it have to apply the the real approach is called communicative language teaching (CLT). According to Manalullaili, (2015) state that one of the key factors of CLT is promoting the effective use of English for second language learners in social interaction. Thus, CLT during process, it aims to make the students are hoped to communicative orally and conquer all components of communicative competence and teacher is being motivator, assesor, facilitator,and corrector during students' discussion or speaking in front of the class.

Futhermore, teachers are evokating the students' courageous to speaking English, becuase the principle in CLT emphasizes on language use rather than on language as structure. This is to say, the need for successful learning of communicative skills of English language suggest communicative ability to be the goal of language teaching. In the other words, to teach English language using comminicative approach becomes essential, Jabeen (2014).

Particularly, to implement CLT approach is needed to increase the students' motivation, which motivation as trigger students to be more active. Therefore, motivation toward learning English is one of the main factors to effect to the students in application for learning English, Souriyawongsa at al., (2012). Thus, according to Baharudin, (2015) argue that motivation is the basic thing to put as the main consideration because all the supporting aspects previously mentioned will be meaningless without it. On the others, Rehman at al., (2014) explain that motivation is considered as an integral part in the achievement of any goal, it is an important factor that has a positive influence in any educational learning process especially in learning second language.

Hence, to increase the students' motivation require special approach which is related to the students' real life. In this research used real material such as the tourism industry as a place to practice their English speaking abilty, through this activity students felt enthusiastics in improving their speaking skill, because the students done it related to their real world. The other reason, students enable to practice their speaking with native speakers directly, because many guests visited in this tourism object. Finally, it enable to say that the tourism industry object which is related to CLT 
approach could give the contribution toward the students speaking motivation in learning English.

\section{Research Questions}

1) How is thecontribution of tourism industry toward students' speaking both of internal and external motivation in English?

2) How is the student's scores of tourism industry toward students' speaking motivation in English?

\section{RESEARCH METHOD}

\section{Research Design}

The present study used mixed method. It contain to be examined in relation to quantitative and qualitative methods of data collection and analysis.

\section{Participants}

The subjects in this research are collaborative students who live around the tourism object (case study at Kencana beach cottages in Labuhan Badas Sumbawa Besar). The participants are 11 students who are going to give such as motivation in order that they would increase their interest and intention to learn English, especially by improving their speaking ability related to tourism industry topic area.

\section{Instruments}

The research instruments employ to collect data for this study are questionnaires, observation, and speaking test. The questionnaires delivered to students. The students' questions consisted of 11 closed-questions design in English.

Together with questionnaires, the researcher used observation to see how the students carry out speaking motivation, how the students performed and what problems the students really encountered in speaking motivation. The researcher observed the students speaking motivation in English. Everything observe, hear, and experience during students speaking motivation in English recorded carefully in detail in the 
following observation sheet. The speaking score generates the pretest and posttest of all the students.

\section{Data collection}

\section{a. Questionnaire}

The researcher explained clearly the purposes of administering the questionnaire about the students' speaking motivation which are to find the students' speaking motivation, the factors affecting their performance and to find ways the students' speaking motivation. The questions had group into two parts, both of them are the intrinsic motivation and extrinsic motivation. Then the researcher gave the instruction to the participants to complete it.

Then, questionnaire sheets distributed to participants. Oral instructions and explanations gave in detail to the participants by the researcher, before they answer the questionnaire to avoid any misunderstandings. After that, the model of Five-point Likert scale was used to measure the level and type of subjects' learning motivation. Such scale was used in the questionnaire to specify the level of the agreement or disagreement based on the following criteria:

Table. 01

\begin{tabular}{|l|l|}
\hline Mean Range & Interpretation \\
\hline $3.68-5.00$ & High degree of Motivation \\
\hline $2.34-3.67$ & Moderate degree of Motivation \\
\hline $1.00-2.33$ & Low degree of Motivation \\
\hline
\end{tabular}

\section{b. Observation}

The researcher first designed the observation sheet. Observation took place four weeks after the questionnaire survey administered. The researcher observed all students' questionnaire sheet.

\section{c. Speaking test by using Conversation}

Pretest and posttest gave to all students. The first, the researcher designed some converstation to measure their ability in oral communication. Then, five treatments after 
pretest the researcher gave conversation as a post test. All the test designed in form of oral test.

There were five English Material for Tourism Industry in this exam. It would be analyzed by using descriptive statistic. Each participant would be gain score Very good (86-100), Good (76-85), Fair (56-74), and Poor (10-55)point.

\section{Data Analysis}

The quantitative data derives from the questionnaires and the speaking test analyzed by comparing the means of each test to find out the general scores of all the participants' speaking motivation. In order to answer the research questions, the descriptive statistics of frequencies and percentages analyzed by using SPSS Program. The qualitative data had derived from the observation. What happened to every observation had been described in details.

\section{RESULT AND DISCUSSION}

\section{Result}

Based on the data pretest analyzed, it was showed that all the participants' ability in speaking skill were poor. There were all eleven participants who gained score 10-55. It means the participants' ability in speaking still under expectation, where the participants' ability will increase their score after give some treatments related to the English Material for Tourism Industry.

1. Descriptive Statistics Pretest Score of the Participants Table. 02

\begin{tabular}{|l|l|l|l|l|l|}
\hline & $\mathrm{N}$ & Minimum & Maximum & Mean & Std.Deviation \\
\hline Pretest & 11 & 26.67 & 43.33 & 32.73 & 4.67 \\
\hline
\end{tabular}

From the table above, it can be seen the mean score of pretest was 32,73. The minimum score of pretest was 26,67 . The maximum score pretest was 43,33 . The standard deviation was 4.67

2. Descriptive Statistics Posttest Score of the Participants 
Based on the data posttest analyzed, it was showed that the participants' ability in speaking skill were poor to fair. There were only four participants who gained score 10-55. There were seven participants gained score 56-74. It means the participants' ability in speaking was increase after give some treatments related to the English Material for Tourism Industry.

Table. 02

\begin{tabular}{|l|l|l|l|l|l|}
\hline & N & Minimum & Maximum & Mean & Std. Deviation \\
\hline Post test & 11 & 43.33 & 70.00 & 57.58 & 8.70 \\
\hline
\end{tabular}

From the table above, it can be seen the mean score of posttest was 57.58. The minimum score of pretest was 43.33 . The maximum score of posttest was 70.00. The standard deviation was 8.70

3. The Result of Mean and Standard Deviation (SD) Questionnaire's Sheet of Instrumental Motivation

Table. 03

\begin{tabular}{|l|l|l|l|l|l|}
\hline $\mathrm{N}$ & $\begin{array}{l}\text { High degree } \\
\text { motivation }\end{array}$ & $\begin{array}{l}\text { Moderate degree } \\
\text { motivation }\end{array}$ & $\begin{array}{l}\text { Low degree } \\
\text { motivation }\end{array}$ & Mean & Std. Deviation \\
\hline 10 & - & 8 & 2 & 29.1 & 4.73 \\
\hline
\end{tabular}

Based on the result of questionnaire's sheet of instrumental motivation, it was showed that there were 8 items moderate degree motivation and 2 items low degree motivation were chosen by participants. By mean range was $2.34-3.67$ to moderate degree motivation and mean range was $1.00-2.33$ to low degree motivation. It means the participants' instrumental motivation still in medium area in speaking motivation related to the English Material for Tourism Industry.

4. The Result of Mean and Standard Deviation (SD) Questionnaire's Sheet of Integrative Motivation

Table. 04

\begin{tabular}{|l|l|l|l|l|l|}
\hline $\mathrm{N}$ & $\begin{array}{l}\text { High degree } \\
\text { motivation }\end{array}$ & $\begin{array}{l}\text { Moderate degree } \\
\text { motivation }\end{array}$ & $\begin{array}{l}\text { Low degree } \\
\text { motivation }\end{array}$ & Mean & Std. Deviation \\
\hline 10 & 6 & 4 & - & 35.5 & 4.27 \\
\hline
\end{tabular}

Based on the result of questionnaire's sheet of integrativel motivation, it was showed that there were 6 items high degree motivation and 4 items moderate degree motivation were chosen by participants. By mean range was $3.68-5.00$ to high degree motivation and mean range was $2.34-3.67$ to moderate degree motivation. It means 
the participants' integrative motivation still in high area in speaking motivation related to the English Material for Tourism Industry.

\section{Discussion}

This present study was conducted at Kencana beach cottages in Labuhan Badas Sumbawa Besar). The subjects of this study were the collaborative students who live around the tourism object. Based on the result of data analyzed above that the Tourism Industry had significant contribution to enhance the Students' Speaking Motivation in Learning English on Students who live around Tourism Object by participate in the joining some English materials Tourism Industry.

It was shown by giving some treatments to the participants related to the English Material for Tourism Industry. Beside the speaking ability, the participant also had the instrumental and integrative motivation in speaking related to the English Material for Tourism Industry. So, the participants who joined some English materials such as Tourism Industry, they increased their speaking ability and had both motivations.

\section{CONCLUSION AND SUGGESTIONS}

Based on the data analysis above, it can be concluded that the Tourism Industry has significant contribution to enhance the students' speaking motivation in learning English. This happens to the students who live around tourism object by participating and joining some English materials of Tourism Industry.

The result of this research has shown that the Tourism Industry has significant contribution to enhance the Students' Speaking Motivation in Learning English. This study is confirmed to have similar result as compared to that of previous inquiries despite not precise. However; some weaknesses are found to be the notes for the next study in the same topic.

Accordingly, these following suggestions are uttered:

a. It is suggested that English teachers must be able choose suitable extracurricular activity to enhance students' learning motivation.

b. It is suggested to the readers who infers for further researcher related to this research should explore the knowledge to enlarge their understanding about how to enhance the speaking's motivation and search another reference. 
c. It is suggested to the further researcher conduct the related issues in another case.

\section{BIO-PROFILE}

Umar was born in Bajo, on 22 July 1973 from the couple of the late Ismail and Halimah. $\mathrm{He}$ is the second child of five children. He finished his S1 degree in English Education Departement of STKIP Hamzanwadi Selong, then he studied at Postgraduate Program of Undiksha on the Language Education Study Program concentrate on English. After that he continued his study again at Doctoral Program of Udayana University majoring at linguistics until now. He has been a lecturer of STKIP Paracendekia NW Sumbawa since 2013 until now.

\section{BIO-PROFILE}

Suparman was born in Lab. Terata, on 7 October 1987 from the couple of the Daeng Sabate and Nurmah. He is the older child of three children. He finished his bachelor degree at Institute of Teacher Training and Education (IKIP) Mataram, majoring at English Eduction Program. He continued his Master Degree majoring at English Education Program at Ahmad Dahlan University (UAD), Yogyakarta. Now, he is a English lecturer at Advanced School of Teachers Training and Education ( STKIP) Paracendekia NW Sumbawa. 


\section{REFERENCES}

Baharudin (2015), Enhancing Students' Motivation in Learning English Grammar Through a Computer- Supported Learning Classroom Manegement. JEELS, 2 (2), 85-107.

Irawati, D.(2016). Supporting Student's English Speaking Achievement Using Video. International Journal of EFL,1 (1), 45-60.

Fauzan, U. (2016). Enhancing Speaking Ability of EFL students through Debate and Peer Assesment. EFL Journal, 1(1),49-57.

Jabeen, S.S. (2014). Implementation of Communicative Approach. English Language Teaching,7 (8), 68-74.

Juniar,R (2016). The Role of Motivation In Learning English for Indonesian Students. International Journal of Manegement and Applied Science, 2 (8),65-68.

Manalullaili, (2015). Applying Communicative Language Teaching in Teaching English for Foreign Language Learners. Ahmad Dahlan Journal of English Studies (ADJES),2(3),1-8.

Utaminingsih, M.N. (2013). Improving Students' Speaking Ability Through Story Board Game. Journal of English Language Teaching,2(2),1-7.

Rehman,A., Bilal,H.A., Sheikh,A., Bibi,N., Nawaz,A. (2014). The Role of Motivation in Learning English Language for Pakistani Learners. International Journal of Humanities and Social Sccience, 4 (1), 254-258.

Souriyawongsa T., Raob I., Abidin Z.J.M. (2012). Study on Students' Motivation in Joining An English Course. Journal of Education and Learning, 6 (3),147-154. 